\title{
Effect of Etching Time and Light Source on the Bond Strength of Metallic Brackets to Ceramic
}

\author{
Paulo Roberto Amaral GONÇALVES ${ }^{1}$ \\ Rafael Ratto de MORAES ${ }^{2}$ \\ Ana Rosa COSTA ${ }^{3}$ \\ Américo Bortolazzo CORRER ${ }^{3}$ \\ Paulo Roberto Aranha NOUER ${ }^{1}$ \\ Mário Alexandre Coelho SINHORETI ${ }^{3}$ \\ Lourenço CORRER-SOBRINHO ${ }^{3}$

\begin{abstract}
${ }^{1}$ Department of Orthodontics, Dental School, São Leopoldo Mandic Research Center, Campinas, SP, Brazil ${ }^{3}$ Department of Restorative Dentistry, Dental Materials Division, Piracicaba Dental School,
\end{abstract} \\ ${ }^{2}$ Department of Restorative Dentistry, Dental School, UFPel - Federal University of Pelotas, Pelotas, RS, Brazil \\ UNICAMP - University of Campinas, Piracicaba, SP, Brazil
}

\begin{abstract}
This study evaluated the bond strength of brackets to ceramic testing different etching times and light sources for photo-activation of the bonding agent. Cylinders of feldspathic ceramic were etched with $10 \%$ hydrofluoric acid for 20 or $60 \mathrm{~s}$. After application of silane on the ceramic surface, metallic brackets were bonded to the cylinders using Transbond XT (3M Unitek). The specimens for each etching time were assigned to 4 groups $(n=15)$, according to the light source: XL2500 halogen light, UltraLume 5 LED, AccuCure 3000 argon laser, and Apollo 95E plasma arc. Light-activation was carried out with total exposure times of 40, 40, 20 and 12 s, respectively. Shear strength testing was carried out after $24 \mathrm{~h}$. The adhesive remnant index (ARI) was evaluated under magnification. Data were subjected to two-way ANOVA and Tukey's test $(\alpha=0.05)$. Specimens etched for $20 \mathrm{~s}$ presented significantly lower bond strength $(p<0.05)$ compared with those etched for $60 \mathrm{~s}$. No significant differences $(p>0.05)$ were detected among the light sources. The ARI showed a predominance of scores 0 in all groups, with an increase in scores 1,2 and 3 for the $60 \mathrm{~s}$ time. In conclusion, only the etching time had significant influence on the bond strength of brackets to ceramic.
\end{abstract}

Key Words: bonding, ceramic, etching time, light source, shear bond strength.

\section{INTRODUCTION}

In addition to dental enamel, restorative materials may sometimes serve as substrates for bonding of orthodontic brackets under clinical conditions. Bonding to ceramic is usually achieved after etching using hydrofluoric acid. The literature presents, however, controversial findings regarding the etching time required for optimal bonding to ceramic. While some authors (1-3) found lower bond strengths associated with increasing etching times, others $(4,5)$ observed that longer etching times may increase the bond strength to ceramic.

Following the acid treatment, the irregularities created on ceramic need to be infiltrated by an adhesive material for bonding. Photo-activated resin agents are usually used for this purpose $(6,7)$. Several lightcuring units (LCUs) presenting varied light sources are available for photo-activation (8-14). In addition to the traditional quartz-tungsten-halogen (QTH) LCUs and the increasingly popular light-emitting diodes (LEDs), plasma arc (PAC) and laser units have been introduced to reduce the curing time. However, literature is still not conclusive regarding the effectiveness of different LCUs for bracket bonding, especially when the bonding substrate is a dental ceramic.

The aim of this study was to investigate the bond strength of metallic orthodontic brackets to feldspathic ceramic mediated by an adhesive resin, testing different times for ceramic etching ( 20 or $60 \mathrm{~s}$ ) and different light sources for photo-activation (QTH, LED, PAC or laser). The null-hypotheses tested were that (i) no significant

Correspondence: Prof. Dr. Lourenço Correr-Sobrinho, Faculdade de Odontologia de Piracicaba, UNICAMP, Área Materiais Dentários, Avenida Limeira, 901, 13414-903 Piracicaba, SP, Brasil. Tel: +55-19-2106-5348. Fax: +55-19-2106-218. e-mail: sobrinho@fop.unicamp.br 
differences would be detected between the etching times, and (ii) no significant differences would be detected among the light sources.

\section{MATERIAL AND METHODS}

\section{Preparation of Specimens}

Four feldspathic ceramic cylinders (Certec Advanced Ceramics, Barueri, SP, Brazil) measuring $15 \mathrm{~mm}$ in diameter and $20 \mathrm{~mm}$ in height were used. The surface of all cylinders was cleaned with pumice/ water slurry before testing. Two cylinders were etched for 20 and two for $60 \mathrm{~s}$ with $10 \%$ hydrofluoric acid gel (Dentsply Caulk, Milford, DE, USA). After etching, the surfaces were rinsed with air-water spray for $20 \mathrm{~s}$ and dried with air for $20 \mathrm{~s}$. Two layers of a silane coupling agent (RelyX Ceramic Primer; 3M ESPE, St. Paul, MN, USA) were applied and dried for $60 \mathrm{~s}$. Stainless steel, standard edgewise incisor brackets (slot 0.022"; Dental Morelli, Sorocaba, SP, Brazil) were bonded to the specimens using Transbond XT light-cured bonding resin (3M Unitek, Monrovia, CA, USA), following the manufacturer instructions.

\section{Light-Curing Procedures}

The brackets were seated and positioned firmly in the ceramic surface. Excess resin was removed using a microbrush and light-activation was carried out using one of the four LCUs tested, as shown in Table 1. The irradiance and light emission spectrum of each LCU were assessed with a power meter (Ophir Optronics Inc., Danvers, MA, USA) and a computer-controlled spectrometer (USB2000; Ocean Optics, Dunedin, FL, USA). Light-activation was carried out with 4 exposures on each side of the bracket. Total exposure times were 40, 40, 20 and $12 \mathrm{~s}$ for XL 2500 (3M ESPE), UltraLume 5 (Ultradent, South Jordan, UT, USA), AccuCure 3000 (LaserMed, West Jordan, UT, USA) and Apollo 95E (DMD, Westlake, CA, USA), respectively. In total, 30 brackets were bonded to each ceramic cylinder ( $\mathrm{n}=15$ for each etching time-light source combination). As several brackets were bonded to the same ceramic cylinder, a punch-holed strip of black adhesive tape was used to avoid light exposure to adjacent brackets, restricting the polymerization light solely to the specimen being bonded. The specimens were stored at $37^{\circ} \mathrm{C}$ and $100 \%$ relative humidity.

\section{Bond Strength Testing and Failure Analysis}

The shear bond test was conducted in a mechanical testing machine after $24 \mathrm{~h}$. A mounting jig was used to align the bracket-ceramic interface parallel to the testing device. The shear load was applied using a knife-edged rod at a crosshead speed of $1 \mathrm{~mm} / \mathrm{min}$ until failure. Bond strength values were calculated in $\mathrm{MPa}$. Data were submitted to two-way ANOVA and Tukey's test $(\mathrm{p}<0.05)$.

A stereomicroscope was used to analyze the debonded ceramic and bracket surfaces (40x magnification). The adhesive remnant index (ARI) was used to classify the failure modes as follows: $0=$ no bonding resin left on the tooth, $1=$ less than half of the bonding resin left on the tooth, 2 = more than half of the bonding resin left on the tooth, and $3=$ all bonding resin left on the tooth, with distinct impression of the bracket mesh.

\section{RESULTS}

Results for bond strength are shown in Table 2. The statistical analysis showed the factor 'etching time' was significant $(p<0.001)$, with specimens etched for 20 $\mathrm{s}$ showing significantly lower bond strengths compared with specimens etched for $60 \mathrm{~s}$. The factor 'light source' was not significant $(\mathrm{p}=0.698)$, neither was the interaction between the two factors studied $(\mathrm{p}=0.919)$. No significant differences in bond strength were detected among the LCUs, irrespective of the etching time.

Results for ARI are shown in Table 3. A predominance of score 0 was observed for specimens etched for $20 \mathrm{~s}$, irrespective of the LCU. On the other hand, despite the large number of scores 0 observed for specimens etched for $60 \mathrm{~s}$, there was an increase in the number of scores 1, 2 and 3 for the longer etching time.

Table 1. Characteristics of the light-curing units.

\begin{tabular}{lccc}
\hline Curing unit & Light source & Irradiance* & $\begin{array}{c}\text { Peak of } \\
\text { emission }\end{array}$ \\
\hline XL2500 & QTH & $800 \mathrm{mWcm}^{2}$ & $484 \mathrm{~nm}$ \\
UltraLume 5 & LED & $1500 \mathrm{~mW} / \mathrm{cm}^{2}$ & $454 \mathrm{~nm}$ \\
AccuCure 3000 & Laser & $500 \mathrm{~mW} / \mathrm{cm}^{2}$ & $487 \mathrm{~nm}$ \\
Apollo 95E & PAC & $1200 \mathrm{~mW} / \mathrm{cm}^{2}$ & $448 \mathrm{~nm}$ \\
\hline
\end{tabular}

*The radiant exposure was 32, 60, 10 and $14.4 \mathrm{~J} / \mathrm{cm}^{2}$ for the QTH, LED, Laser and PAC, respectively. 
Regarding the LCUs, no appreciable differences were detected with respect to the failure analysis. Failure scores were independent of the light source.

\section{DISCUSSION}

The first null hypothesis was rejected, as higher bond strengths were detected for specimens etched for $60 \mathrm{~s}$ compared with $20 \mathrm{~s}$, irrespective of the LCU. Effective bonding to ceramic is dependent on creating sufficient retention for micromechanical interlocking with the bonding resin. According to Yen et al. (15), hydrofluoric acid starts etching the ceramic by reacting preferentially with the silica phase, creating retentive microchannels. With time, the acid reacts with the glassy matrix, partially dissolving it, increasing the formation of retentive channels. Therefore, longer etching times may create more irregularities for bonding, explaining the results of the present study.

According to Reynolds (16), bond strength values in the range of 6 to $8 \mathrm{MPa}$ are necessary for bonded brackets to withstand the mechanical forces taking place in the oral environment. In the present study, bond strength values lower than $6 \mathrm{MPa}$ were detected only for some groups in which the ceramic surfaces were etched for $20 \mathrm{~s}$. This indicates that a $20 \mathrm{~s}$ etching time with $10 \%$ hydrofluoric acid might be insufficient for creating retention for proper bonding of orthodontic brackets to feldspathic ceramic.

With regard to the light-curing procedures, no significant differences among the LCU were detected, confirming the second null hypothesis. Dall'Igna et al. (8) also found no significant differences among the LCU units. However, Cekic-Nagas et al. (10) showed significant difference between LED and QTH and PAC units. Photo-polymerization is dependent on the

Table 2. Means (SD) for shear bond strength (MPa).

\begin{tabular}{|c|c|c|}
\hline \multirow{2}{*}{$\begin{array}{l}\text { Light } \\
\text { source }\end{array}$} & \multicolumn{2}{|c|}{ Etching time } \\
\hline & $20 \mathrm{~s}$ & $60 \mathrm{~s}$ \\
\hline QTH & $6.26(1.2)^{a, B}$ & $8.63(2.0)^{a, A}$ \\
\hline LED & $6.45(1.0)^{a}, \mathrm{~B}$ & $8.38(1.3)^{\mathrm{a}, \mathrm{A}}$ \\
\hline Laser & $6.44(1.0)^{a}$, B & $8.21(1.1)^{\mathrm{a}, \mathrm{A}}$ \\
\hline PAC & $5.95(1.4)^{a, B}$ & $8.00(1.1)^{\mathrm{a}, \mathrm{A}}$ \\
\hline
\end{tabular}

Uppercase letters in rows and lowercase letters in columns indicate statistically significant difference $(\mathrm{p}<0.05)$. radiant exposure (17). Radiant exposure is the product of irradiance and exposure time (17). LED and QTH supplied the highest radiant exposure during photoactivation $\left(60\right.$ and $\left.32 \mathrm{~J} / \mathrm{cm}^{2}\right)$. Laser $\left(10 \mathrm{~J} / \mathrm{cm}^{2}\right)$ and PAC $\left(14.4 \mathrm{~J} / \mathrm{cm}^{2}\right)$ presented radiant exposure much lower than the others light sources. However, as the emission spectrum of the laser is concentrated on the absorption peak of camphorquinone (at $468 \mathrm{~nm}$ ), it promoted effective photoactivation. The absence of differences for PAC might be explained by the fact that a very thin resin layer is necessary for bracket bonding, and thus the differences in energy dose were probably not great enough to influence the bond strengths.

The increase in the number of ARI scores 1, 2 and 3 for the $60 \mathrm{~s}$ etching time is probably a result of increased retention created on the surface, enhancing the mechanical interlocking of the bonding resin to ceramic and, thus, generating failures involving the bonding material, not only adhesive failures. This finding is in line with those from Olsen et al. (18), who showed decreased etching times might affect not only the bond strengths of orthodontic brackets, but also the mode of failure to the bonding substrate.

The present results indicate the etching time is a decisive factor for the bond strength of brackets to ceramic. Although clinicians should follow the manufacturers' recommendations for bonding procedures, a 60 s etching time for bonding to feldspathic ceramic might be recommended. However, care should be taken when selecting the etching time for each substrate, as previous studies have shown negative effects of over-etching ceramics, such as difficult penetration of the bonding agent into the irregularities and possible cohesive failure of the substrate $(1-4,19,20)$. On the other hand, although the light source presented

Table 3. Results for the failure analysis (ARI scores).

\begin{tabular}{lccccc}
\hline \multirow{2}{*}{$\begin{array}{l}\text { Light } \\
\text { source }\end{array}$} & $\begin{array}{c}\text { Etching } \\
\text { time (s) }\end{array}$ & \multicolumn{5}{c}{ ARI score (\%) } \\
\cline { 3 - 6 } QTH & 20 & 100 & 1 & 2 & 3 \\
\hline \multirow{2}{*}{ LED } & 60 & 73.4 & 13.3 & - & 13.3 \\
& 20 & 66.7 & 26.6 & - & 6.7 \\
& 60 & 46.6 & 40 & 6.7 & 6.7 \\
\multirow{2}{*}{ Laser } & 20 & 86.7 & 13.3 & - & - \\
& 60 & 53.4 & 33.3 & - & 13.3 \\
\multirow{2}{*}{ PAC } & 20 & 100 & - & - & - \\
& 60 & 60 & 20 & 6.7 & 13.3 \\
\hline
\end{tabular}


no significant influence, the use of high-intensity units is still recommended to ensure effectiveness of polymerization of the bonding resin. Finally, clinicians should be aware of the harmful effects of hydrofluoric acid and take care during its clinical application.

\section{RESUMO}

Este estudo avaliou a resistência de união de bráquetes à cerâmica testando diferentes tempos de condicionamento e fontes de luz para fotoativação do agente de união. Cilindros de cerâmica feldspática foram condicionados com ácido fluorídrico $10 \%$ por 20 ou 60 s. Após aplicação de silano na superfície da cerâmica, bráquetes metálicos foram colados aos cilindros utilizando Transbond XT (3M Unitek). Os espécimes de cada tempo de condicionamento foram divididos em 4 grupos $(n=15)$ : fonte halógena XL2500, LED UltraLume 5, laser de argônio AccuCure 3000 e arco de plasma Apollo 95E. A fotoativação foi realizada com tempo total de 40, 40, 20 e $12 \mathrm{~s}$, respectivamente. O teste de cisalhamento foi realizado após $24 \mathrm{~h}$. O índice de adesivo remanescente (IAR) foi avaliado sob aumento. Os dados foram submetidos a ANOVA de duas vias e teste de Tukey $(\mathrm{p}<0,05)$. Espécimes condicionados por $20 \mathrm{~s}$ apresentaram resistência de união significativamente menor que espécimes condicionados por $60 \mathrm{~s}$. Não foram detectadas diferenças significativas entre as fontes de luz. O IAR mostrou predominância de escores 0 para todos os grupos, com aumento nos escores 1, 2 e 3 para o tempo $60 \mathrm{~s}$. Em conclusão, apenas o tempo de condicionamento teve influência significativa na resistência de união de bráquetes à cerâmica.

\section{REFERENCES}

1. Barghi N, Fischer DE, Vatani L. Effects of porcelain leucite content, types of etchants, and etching time on porcelaincomposite bond. J Esthet Restor Dent 2006;18:47-52.

2. Nagayassu MP, Shintome LK, Uemura ES, Araújo JE. Effect of surface treatment on the shear bond strength of a resin-based cement to porcelain. Braz Dent J 2006;17:290-295.

3. Shimada Y, Yamaguchi S, Tagami J. Micro-shear bond strength of dual-cured resin cement to glass ceramics. Dent Mater 2002; 18:380-388.

4. Chen JH, Matsumura H, Atsuta M. Effect of different etching periods on the bond strength of a composite resin to a machinable porcelain. J Dent 1998;26:53-58.

5. Guler AU, Yilmaz F, Yenisey M, Guler E, Ural C. Effect of acid etching time and a self-etching adhesive on the shear bond strength of composite resin to porcelain. J Adhes Dent 2006;8:21-25.

6. Kasuya K, Miyazaki Y, Ogawa N, Maki K, Manabe A, Itoh $\mathrm{K}$, et al.. Efficacy of experimental dual-cure resin cement for orthodontic direct bond system. Orthod Waves 2006;65:107-111.

7. Meguro D, Hayakawa T, Kasai K. Efficacy of using orthodontic adhesive resin in bonding and debonding characteristics of a calcium phosphate ceramic bracket. Orthod Waves 2006;65:148154.

8. Dall'Igna CM, Marchioro EM, Spohr AM, Mota EG. Effect of curing time on the bond strength of a bracket-bonding system cured with a light-emitting diode or plasma arc light. Eur J Orthod 2011;33:55-59.

9. Correr AB, Sinhoreti MA, Sobrinho LC, Tango RN, Schneider LF, Consani S. Effect of the increase of energy density on Knoop hardness of dental composites light-cured by conventional QTH, LED and xenon plasma arc. Braz Dent J 2005;16:218-224.

10. Cekic-Nagas I, Egilmez F, Ergun G. The effect of irradiation distance on microhardness of resin composites cured with different light curing units. Eur J Dent 2010;4:440-446.

11. Thind BS, Stirrups DR, Lloyd CH. A comparison of tungstenquartz-halogen, plasma arc and light-emitting diode light sources for the polymerization of an orthodontic adhesive. Eur J Orthod 2006;28:78-82

12. Filipov IA, Vladimirov SB. Residual monomer in a composite resin after light-curing with different sources, light intensities and spectra of radiation. Braz Dent J 2006;17:34-38.

13. Park JK, Hur B, Ko CC, García-Godoy F, Kim HI, Kwon YH. Effect of light-curing units on the thermal expansion of resin nanocomposites. Am J Dent 2010;23:331-334.

14. Price RB, Labrie D, Rueggeberg FA, Felix CM. Irraciance differences in the violet $(405 \mathrm{~nm})$ and blue $(460 \mathrm{~nm})$ spectral ranges among dental light-curing units. J Esthet Restor Dent 2010;22:363-377.

15. Yen TW, Blackman RB, Baez RJ. Effect of acid etching on the flexural strength of a feldspathic porcelain and a castable glass ceramic. J Prosthet Dent 1993;70:224-233.

16. Reynolds IR. Composite filling materials as adhesives in orthodontics. Br Dent J 1975;138:83.

17. Rueggeberg F. Contemporary issues in photocuring. Compend Contin Educ Dent Suppl 1999;4-15.

18. Olsen ME, Bishara SE, Boyer DB, Jakobsen JR. Effect of varying etching times on the bond strength of ceramic brackets. Am J Orthod Dentofacial Orthop 1996;109:403-409.

19. Sant'Anna EF, Monnerat ME, Chevitarese O, Stuani MB. Bonding brackets to porcelain - in vitro study. Braz Dent J 2002;3:191-196.

20. Canay S, Hersek N, Ertan A. Effect of different acid treatments on a porcelain surface. J Oral Rehabil 2001;28:95-101.

Accepted March 10, 2011 